\title{
Cornelius de Pauw and the Degenerate Americas
}

\author{
Helen Piel
}

\section{Introduction}

The journals of travellers, or their reports back home, have always offered fascinating insights into the unknown for those left behind. But they are not the only source about exotic places that have been available to the interested reader. As there have been travel accounts, there also always have been books and analyses by writers who had never left their home country. This chapter will deal with one of these books. First published in two volumes in 1768 and 1769, Les Recherches Philosophiques sur les Américains, ou Mémoires Intéressante pour servir à l'Histoire de l'Espèce Humaine made its formerly unknown author almost instantly into one of the most-discussed writers of his time. The Dutchborn clergyman Cornelius de Pauw was going to be the centre of cultural attention for the rest of his lifetime, to be translated almost immediately into German and Dutch, and to be asked to contribute to the Encyclopédie. His fame was not only due to his early work: two more philosophical dissertations followed, first on the Egyptians and Chinese (1773) and then on the Greek (1787/88). His second work again caused great discussion, which epitomised in Voltaire writing his Lettres chinoises, indiennes et tartares à M. Pauw, par un bénédictin (1776) in defence of the Asian nations against de Pauw's polemic.

Today, however, Cornelius de Pauw is as good as forgotten and in my opinion wrongly so. Despite what one scholar called an "exceedingly uneventful" life (Church, 1936, p.181), the clergyman is a fascinating character, which admittedly is probably revealed more through 
his writing than his acting. He understood to popularise and polemicise topics that were much debated among scholars and in courts. His writing style was fashioned after the encyclopedists, his tone was characterised by the "leicht geschürzte(n) Plauderton des Friderizianischen Salons" - the "slightly arrogant conversation tone of the Frederickian salon"1 (Beyerhaus, 1926, p.470). On top of offering an explanation for de Pauw's great success during his lifetime, all this makes his work still very accessible today. Why he then sank into oblivion so soon after his death, will not be part of this chapter however. Instead, it will focus on his first work, the Recherches sur les Américains, and deal with it in relation to its depiction of the American peoples as well as in relation to the so called "degeneracy theory", which is the idea that the New World is inferior to the Old - an idea that has prevailed to our days in the form of anti-Americanism.

Originally, the French naturalist Count de Buffon had developed the idea of degeneration as a mechanism for change - change which, incidentally, could also be brought about via improvement, and which applied to animals both in the New and the Old World. In his essay, de Pauw then follows up on this. He not only elaborates on it but, more importantly, he transforms it into a theory of degeneracy applying to America alone and with all negative connotations this brings. Moreover, by extending it to immediately affecting Europeans settling in America he makes it highly controversial. The question that now arises is firstly how de Pauw's writing about the indigenous peoples of the Americas conveys a representation of non-European peoples, and secondly how this ultimately contributes to his general depiction of the Americas as degenerate.

\section{Setting the Stage}

Part of what makes the Recherches Philosophiques sur les Américains (hereafter referred to as the Recherches) such an interesting read is its historical context. Cornelius de Pauw lived in Prussia during the period of the Enlightenment. The Enlightenment was characterised by a belief in progress and that "the conditions of human life become better as time goes on" (Palmer \& Colton, 2006, p.298). The main and best-known enterprise of the Enlightenment and the philosophes is surely the Encyclopédie edited by Denis Diderot and published between 1751 and 1772, to which de Pauw was asked to contribute shortly after the publication of the Recherches. Philosophes in this context is used "to denote a group of writers who were not philosophers in the sense of treating ultimate questions of knowledge or existence.

1 The translations of the originally German quotations into English are my own. 
They were social or literary critics, popularizers, and publicists" (p.300), a fact that is clearly eminent in the Encyclopédie with its socially critical undercurrent and emphasis on reason, and also very much in the writings of de Pauw.

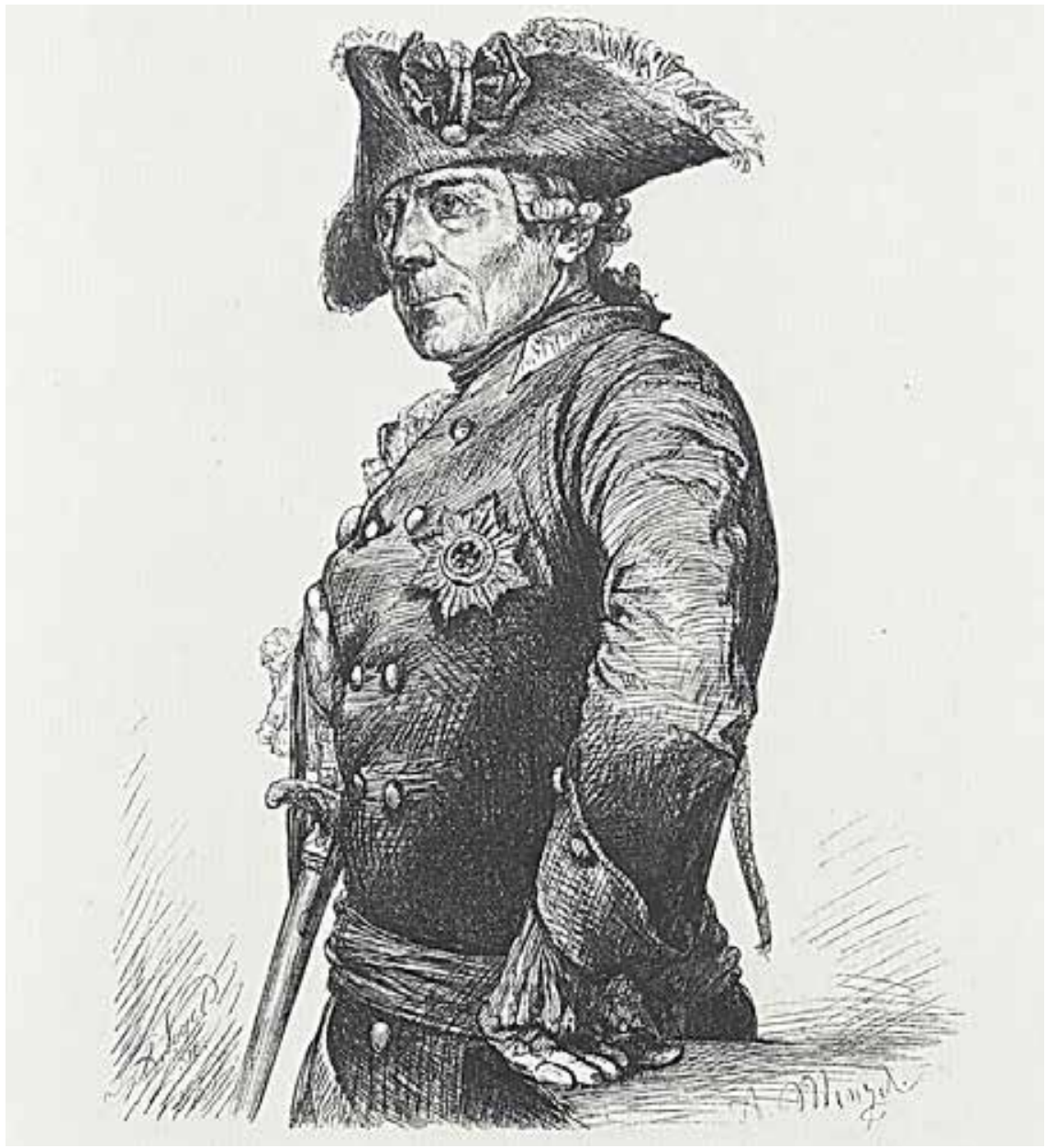

Fig. 1: At his court in Sanssouci, Frederick the Great (1712-1786) had gathered a Round Table of philosophes, among which was most notably Voltaire, and to which de Pauw was introduced in 1767. The relationship between the clergyman and the king has very likely played a role in the great success of de Pauw's writings.

Source: Drawing by Adolf Menzel (1815-1905), retrieved May 12, 2013 from http://www.kunstdruckeaufleinwand. org/Adolf\%2oMenzel/Zeichnungen/Friedrich-der-Grosse.jpg.php 
Prussia during the eighteenth century is known for both its wars and its reforms, for instance in civil law (cf. Stolberg-Wernigerode, 1961). These ambiguous traits relate back to the reign of Frederick II, himself a fascinating figure and already in his lifetime known as Frederick the Great. Especially German historians tend to praise his achievements whereas his "best-known non-German biographer, Thomas Carlyle, confessed to the greatest difficulty in hiding his disgust for the man" (Ingrao, 1986, p.165). In line with the idea of the "enlightened absolutism", Frederick - a philosophe and published writer himself - had gathered a round of philosophers and free thinkers at his court in Sanssouci. The most memorable member of his Round Table is surely Voltaire who stayed with the king between 1750 and 1753 and whom Frederick admired greatly (cf. Stolberg-Wernigerode, 1961). In 1767, just before the publication of the Recherches, de Pauw was introduced into this environment and to the King himself. The clergyman stayed at the court for several months before he returned to Xanten and worked on his first publication.

It is this first stay at the court during which de Pauw was private reader to the Prussian king - there followed a second one about a decade later - that has incited Dúran Echevarría to associate the Recherches' polemical nature with the king's anti-emigration politics (cf. Dugatkin, 2009, p.36). Frederick the Great was so determined to stop Prussians from taking their money and leaving to the Americas that he even "set up an agency in Hamburg to discourage would-be emigrants" (Browning, 1978, p.292). Indeed, even though Frederick himself is not mentioned in the work's preface, its explicit warning against any attempts to conquer the New World makes such a connection very probable. De Pauw refers to the writings that encourage such conquests as "verfänglich" - as "potentially dangerous" (de Pauw, 1769a, p. ${ }^{*}$ ) and repeatedly foregrounds the disadvantages the discovery of America has brought to the Europeans: "so haben wir doch niemals aus Amerika die vermeynten Vortheile ziehen können"- "never have we been able to benefit from America as expected" (p.70).

It needs to be noted however that de Pauw's aversion to conquests was also very much part of his Enlightenment background. Other philosophes were also arguing against imperialism. For instance Denis Diderot, co-editor of the Encyclopédie, condemned European imperialism on the grounds of the cruelties inflicted upon non-European peoples but also on the grounds of the negative effects colonies had on the European countries (cf. Muthu, 2003). These sentiments are also mirrored in de Pauw who attacks the behaviour of the Spanish in America and blames their political downfall upon their involvement in the New World (cf. de Pauw, 1769a, p.62 +68).

More generally speaking there is a much more mundane context to de Pauw's interest in America. His book by far was not the first, and definitely not the last, on the New World. 
Ever since its discovery had it interested Europeans, and especially in the second half of the eighteenth century all eyes were directed at the colonies. The British had increased their territory with the end of the Seven Year's War in 1763, gaining control over Canada and many other formerly French and Spanish territories in North America. However, at the same time tensions with the colonies were arising or rather increased by the issuing of several laws. The 1750 Iron Act curtailed the colonies' iron industry in protection of the British industry, the 1764 Sugar Act regulated the import of several goods, and the 1765 Quartering Act required that Americans give quarters and food to British soldiers. But it was the Stamp Act of the same year that in particular angered the colonists, for it meant that "for the first time in the 150 year old history of the British colonies in America, the Americans will pay tax not to their own local legislatures in America, but directly to England" (cf. Taylor, n.d.). All these events ensured a continued interest in America, and de Pauw's book, by offering an analysis and summary of much that was known about the New World by the end of the eighteenth century, was sure to have a wide readership, "dramatically increased" by the author's relationship to Frederick the Great (Dugatkin, 2009, p.36).

\section{Enter Cornelius de Pauw}

Cornelius de Pauw's own background clearly adds much to the fascinating context of his Recherches. He is born in the prosperous city of Amsterdam in August 1739. His family name is spelled various different ways, Pauw or Paw, with or without the de, and he himself is sometimes also referred to as Corneille de Pauw, simply as Abbé de Pauw or, in his Recherches sur les Américains, anonymously as Mr. de P*** (cf. Church, 1936, p.178). Whereas the biographical data on de Pauw's later life is rather consistent, if scarce, you cannot say the same about his ancestry and youth. In his article Corneille de Pauw, and the Controversy over his 'Recherches Philosophiques sur les Américains' (1936), Henry Ward Church gives an analytical overview over the available sources. He concludes that while we cannot be sure about the paternal relatives,

“(a)Il authorities are agreed that on the maternal side Corneille had two illustrious relatives who, like himself [...], were noted for courage and independence of mind. He was the grand-nephew of the great Corneille de Witt, and was the uncle of Anacharsis Cloots, picturesque Jacobin member of the Convention and victim of the ever active guillotine of Robespierre" (p.180). 
The fact that the relation to Anacharsis Cloots is also noted in older sources such as the multi-volume $19^{\text {th }}$ century "Biographisch Woordenboek der Nederlanden" by A.J. van $\operatorname{der} A a$, a source about fifty years closer to de Pauw's lifetime, lends weight to this part of de Pauw's biography. Sources are then divergent with regard to the education de Pauw received. It seems that he is educated at the Jesuit colleges in Liège and Cologne, after being orphaned at a young age. A stay at the University of Göttingen, however, cannot be confirmed. According to Gisbert Beyerhaus "[ist] (e)ine Immatrikulation nicht nachzuweisen"- "a matriculation cannot be proved" (cf. 1926, p.466). Still, even if one takes the attraction to protestant Göttingen as simply that, an attraction, and not as an actual part of de Pauw's biography, it can be seen as "symptomatisch" - "symptomatic" (ibid.) for the following free thinking work of the Catholic clergyman.

As already mentioned, about de Pauw's later life there is less ambiguity. In 1761 his brother-in-law, baron Thomas Cloots - the father of the already mentioned Anacharsis Cloots - places him as canon in the diocese of St Victor in Xanten, where he stays until the end of his life. Four years later he is consecrated sub-deacon in Liège and made head of the library of St Victor. At the age of twenty-eight, de Pauw is sent to Berlin in order to sort out an administrative issue for the diocese (cf. p.467). During this diplomatic mission he is introduced to Frederick II, King of Prussia, the aforementioned representative of enlightened absolutism and a widely read author himself. De Pauw leaves the court after eight months, in spite of the king's wishes for him to stay longer; the clergyman prefers the seclusion of his study in Xanten:

"Wenn er damals die Rückkehr nach Xanten gleichsam erzwang, so war es die Sehnsucht des Kulturmenschen nach einem beschaulichen Wirken und schriftstellerischer Muße, die inn trieb" - "When he rather forced his return to Xanten, it was the desire of the man of culture for a contemplative working and the leisure of writing that were driving him" (p.468).

In 1768, the year of his return to Xanten, he then publishes the first volume of his Recherches Philosophiques sur les Américains, with the second volume following the next year. These philosophical dissertations on America and the Americans turn the formerly unknown Dutchman quickly into one of the most widely read philosophers of his time. "His books passed through edition after edition, and were translated from the original French into English, Dutch, and German" (Church, 1936, p.178). Two more dissertations follow: in 1773 de Pauw publishes Les Recherches Philosophiques sur les Égyptiens et les Chinois, followed in 1787 by Les Recherches Philosophiques sur les Grecs, both of which are as much discussed 
- and criticised - as his early work ${ }^{2}$. His success and position as a philosophe is furthermore underlined by the fact that soon after his first publications, de Pauw is approached by Diderot and d'Alembert, the editors of the Encyclopédie, who seek his participation for this major work of the Enlightenment (cf. Beyerhaus, 1926, p.478).

At the king's request, de Pauw once again spends a few months at the court of Frederick the Great in 1775, but as before, and again despite the king's attempts to keep him in his vicinity, the clergyman soon returns to Xanten. On July 7,1799 Cornelius de Pauw dies at the age of sixty. He soon sinks almost "completely out of sight" and today "his name is only in the largest encyclopledias" (Church, 1936, p.178).

\section{Ten Years of Labour Enter the Market}

It is time now to go more into detail about Les Recherches Philosophiques sur les Américains and to set it into relation with its historical context. When de Pauw published his first major work, the discovery of America dated back over two hundred and fifty years. Quite a vast literature had amounted by then, spanning from the first reports by Christopher Columbus and the following conquistadores to reports, letters and diaries from missionaries, merchants, settlers and naturalists. Taking this as the basis for his dissertations - not an unusual practice at the time -, de Pauw compiles a work that analyses and criticises about everything that he has read about the Americas.

"The Américains, as the author insists, are the result of ten years of labor. The amount of reading and research required for the work convinces us that De Pauw is not exaggerating. To have produced such a work before the age of thirty was a scholarly achievement." (Church, 1936, p.184f)

Thus, without ever having been to America, de Pauw becomes well-versed on the New World. As he states in his preface, the significance of the topic, and the reason for writing on the Americans, lies in the fact that the Americans constituted the most important, but also the least known, part of the history of man: "Da die Amerikaner den wichtigsten, aber auch unbekanntesten Theil in der Geschichte des Menschen einnehmen, so haben

2 For a more detailed account on the reactions to de Pauw's Recherches Philosophiques sur les Égyptiens et les Chinois, with a special focus on Voltaire's reaction, I recommend Gisbert Beyerhaus' article Abbé de Pauw und Friedrich der Große, eine Abrechnung mit Voltaire (1926). 
wir uns vorgesetzt, sie zum Hauptgegenstand unserer Untersuchungen zu machen" (de Pauw, 1769a, p.1).

De Pauw's publication hit a central nerve of eighteenth century-circles. His writing was fashioned with regard to content after the Encyclopédie, with regard to style after the light to biting conversation tone of the salons, and the almost instant and complete translations into German (1769) and Dutch (1771-72) show its popularity not only with the French-speaking intelligentsia. The highly polemical and popularising theories surely contributed to the book's success, and before the end of the century it went through eleven editions in four languages ${ }^{3}$. Publications of the year 1770 clearly show the divided reception of the Recherches: on the one hand, Isaak Iselin's review of the German edition is highly positive, criticising only de Pauw's sometimes discrediting treatment of esteemed writers but agreeing to most of his arguments. On the other hand, the second French edition includes a third volume in which both an attack on the Recherches by Dom Pernety (Frederick the Great's royal librarian, cf. Antoine-Joseph Pernety, n.d.) and de Pauw's following defence are published.

De Pauw's printer of choice is also worth noting: five of the seven French editions and the German edition were printed by Georg Jacob Decker in Berlin. Decker printed among others for the Akademie der Wisschenschaften in Berlin and in 1765 became court printer to Frederick the Great (cf. Salzmann, 1957). The significance of this choice is at least twofold. According to Antonello Gerbi, Berlin in 1768, the place and time of the first edition, was "the date and location of encyclopedism at its most glorious and triumphant" (2010, p.52). De Pauw thus clearly wished to establish himself as one of the philosophes, and his following contribution to the Encyclopédie is a clear sign of his success. In addition, by choosing Berlin and the Prussian royal printing house for the first and most of the following editions of the Recherches de Pauw emphasised his connection to Frederick the Great. He might not have liked the life at court, but still he seemed to have shared many of the king's ideas. Thus, this choice also adds validity to Echevarria's abovementioned claim which linked part of the motivation for the book back to Frederick's anti-emigration politics. In his book Mr. Jefferson and the Giant Moose, Lee Alan Dugatkin (2009) connects this claim more elaborately to de Pauw's possible intentions for writing the Recherches.

3 The English editions, published in 1789, 1795 and 1806 and printed privately by R. Cruttwell in Bath, did not comprise a complete translation of the original but excerpts from it, in addition to excerpts from de Pauw's second work on the Egyptians and Chinese. The selection was made by Mr Daniel Webb, an author mostly of works of art (cf. Carlyle, 1899), who explicitly translated de Pauw for his friends: "Care will be taken, it is hoped, that this Copy may not fall into the hands of a Publisher, as but a few have been printed for the Author's Friends" (1789, Notice to the Reader). 
Wondering why the clergyman wrote his dissertations even after the Count de Buffon had already established the idea of degeneration - the idea that, transformed into the theory of degeneracy, determines the tone throughout the Recherches, as will be shown later - he concludes that:

"Part of the answer probably lay in the general fear that many Europeans had regarding the potential of the New World. While financial opportunities in this New World certainly awaited risk takers, the idea that Europeans could now emigrate and obtain vast tracts of land on the other side of the globe was not necessarily appealing to Old World monarchs." Moreover, "(a)fter having so warmly welcomed de Pauw into his court, Frederick may have received an elaborate "thank you" from de Pauw in the form of Philosophical Researches." (p.36)

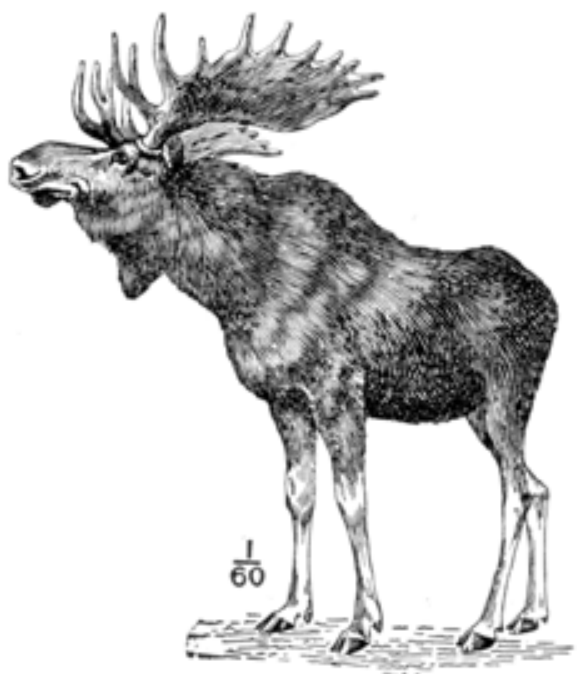

Moose, p. 1404.

Fig. 2: In his famous attempt to disprove the degeneracy theory, Thomas Jefferson had a majestic moose hunted and the skeleton, hide and antlers shipped to Paris where he personally showed it to Count de Buffon. Buffon apparently acknowledged it but died before he could revise the necessary parts in his Histoire Naturelle.

Source: Encyclopédie, ou Dictionnaire raisonné des sciences, des arts et des métiers (1751-1780). Retrieved May 11, 2013 from http://commons.wikimedia.org/wiki/File:Elch.PNG 


\section{The Recherches Philosophiques in Short}

Now that the stage is set it is time to turn to the content of de Pauw's writing. In his twenty five pages-long review of 1770, Isaak Iselin spends the first twenty pages just on a summary of the Recherches. I will limit myself to a fraction of this but would like to give one illustrative citation from Iselin's writing:

"Endlich fasset $\mathrm{Hr}$. von $\mathrm{P}^{* *}$ den Charakter des amerikanischen Wilden, in folgendem

Gemählde zusammen. Sein ganzer Charakter bestehet in seinem thierischen Naturtriebe. Er ist eigentlich weder tugendhaft noch böse." - "Finally Mr. de P** summarises the character of the American savage in the following picture. His whole character consists in his animal instinct. He is neither virtuous nor vicious." (Iselin, 1770, p.123)

These sentences nicely show several aspects of the Recherches. Firstly the essay primarily deals with the history of the American indigenous peoples, describing their physical appearance, their character, customs and manners. De Pauw's conclusion is, as Iselin writes, that the Americans are very much driven by their animal instincts. They have no abstract concepts of love, no numerical system, no understanding of the use of money or of art or beauty - indeed, they have a "falsche Idee von der Schönheit und körperlichen Vortreflichkeit" - a "wrong idea of beauty and physical excellence" (de Pauw, 1769a, p.120).

However, while they are lazy and stupid and would not act unless necessity actually demands it (cf. p.96), they are not vicious or evil in themselves but their character is determined by the conditions of their habitat: the reason for this wretched existence of the American lies according to de Pauw in his cold and wet temperament which is ultimately due to the unfavourable climate of America. This climate - incidentally also wet and cold - is most likely owed to a not too ancient flood or a similar catastrophe that drove the American peoples, as well as the animals, onto the highest peaks of their mountains. When the flood retreated and they returned to the low lands, these were far from dried out, and would not be for considerable time. As a result, life in the New World is degenerate and in an early stage of development. Agriculture alone, for de Pauw, can lead man from one level to the next (cf. de Pauw, 1769a, p.77) and he classifies civilisations according to their way of supplying themselves with food: agriculture is the highest of forms, followed by foraging, fishing and, lastly, hunting. Humanity is therefore in different stages of development (stadial theory, cf. Thompson, 2011, p.146). According to Webb, the translator of the English Selections (1789), “( $t$ ) his statement of the subject is ingenious. It is happy" (p.108). 
The degenerate character of the Americas is not limited to human life, but to the entire fauna and flora. Indeed, only such animals that were - and still are - considered as repulsive, such as most insects, spiders, or reptilians, were thriving in the New World. All other animals are found smaller than their counterparts in the Old World - smaller by one sixth, to be precise (cf. p.4). However, it is de Pauw's ingenious integration of man into his theory of degeneracy which accounted for his most controversial and polemical argument.

In addition to de Pauw's elaboration on the degeneracy theory are harsh attacks on the "nie wahrheitsliebenden" - "ever untrustworthy" Jesuits (p.47), the pope and the Spanish. From the conquest of the Americas, according to the clergyman, Europeans could not benefit as expected but rather suffered from it (cf. p.70). Moreover, he strongly criticises many if not most of his sources: "Manche Leute können eher um die Welt reisen, als die Wahrheit sagen" - "Some people can rather travel around the world than speak truthfully" (p.237). In short the Recherches is thus a polemical essay covering the nature of the American continent and peoples, integrating arguments about civilisation and about the advantages or rather disadvantages the discovery of America has brought for Europe.

\section{The Peoples of the New World}

To go more into detail it is worth taking a look at the following argument of de Pauw, forming a rebuttal of the thesis that the American peoples are all the same:

"Viele Schriftsteller haben behauptet, das menschliche Geschlecht sey in Amerika nicht so verschieden, als in unsrer Welt, alle Gestalten und Gesichter glichen sich, und die Maske des Menschen bliebe immer die nehmliche." - "Many writers have claimed that the human race were not so varied in America as it is in our world, that all forms and faces were similar, and the mask of man always stayed the same." (de Pauw, 1769a, p.103). 
In his Recherches, then, de Pauw distinguishes several varieties of the American peoples, such as the Eskimos, the Patagonians, the Blafards or White Negroes, the Orang-Utans ${ }^{4}$, and the Hermaphrodites of Florida, to mention only those that were given separate headings. By describing these, the clergyman creates a curious image of the peoples of the New World, which is emphasised moreover by the overall narrative of the essay.

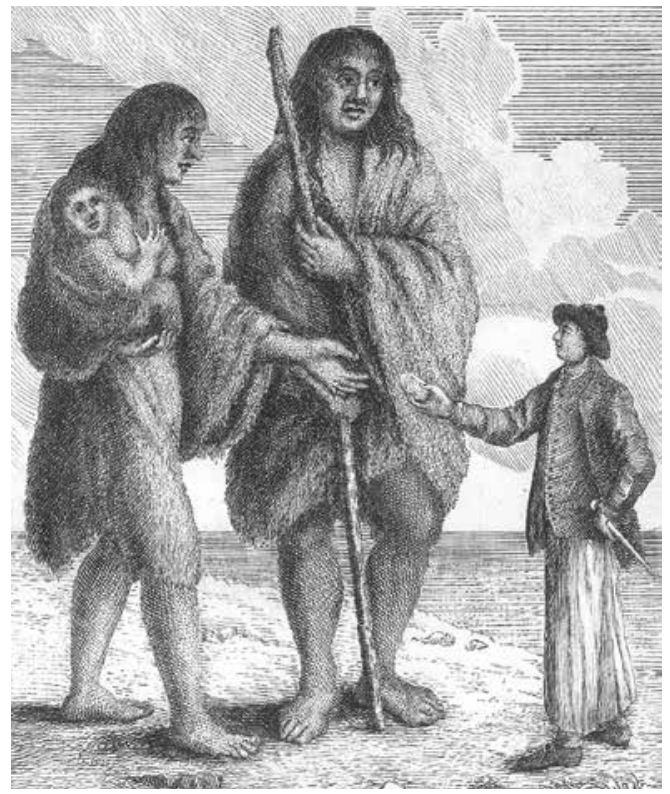

Fig. 3: In the Section "Of the Patagonians" (Vol. I), de Pauw argues vehemently against the existence of giants in Patagonia. According to him, animal fossils have been mistaken for human bone and the alleged eyewitnesses have either been subject to optical illusions or are not trustworthy.

Source: English sailor offering bread to a Patagonian woman giant. Frontispiece to Viaggio intorno al mondo fatto dalla nave Inglese il Delfino comandata dal caposqadra Byron (Florence, 1768), the first Italian edition of John Byron's A Voyage Round the World in His Majesty's Ship the Dolphin ... (London, 1767) [Rare Books Division]. Retrieved May 10, 2013 from http://libweb5.princeton.edu/visual_materials/maps/websites/pacific/magellanstrait/patgonian-giants.html

4 There are, according to de Pauw, only three main differences between the orang-utan and man: orangutans have two additional ribs, their foreskin is missing a certain sinew, and the joints of their toes are longer (cf. de Pauw, 176gb, p.43f). However, these differences are only minor, as they vary between both human and orang-utan individuals, and thus he concludes that the orang-utan is a "Mittelwesen" - an "intermediate being" between human and ape, to use Iselin's summarising words (1770, p.130). 
Interestingly, de Pauw chooses to end his first volume, which in the original French edition was published one year in advance of the second, with one section about the Eskimos and one about the Patagonians respectively. These two peoples live at the very extremes of the American continent: the former in its extreme north, the latter in its extreme south. The clergyman thus gives an overarching account of the American peoples which he then fills in in the second volume. The Patagonians, moreover, were a people surrounded by mysterious stories of them being giants. In effect this seems to be quite a stylistic device to whet the reader's appetite for the following part of the Recherches.

The Eskimos are, according to de Pauw, "die merkwürdigste (Verschiedenheit)" - "the most curious (variance)" (1769a, p.103) of the northern American peoples. They live in the very north of the continent, straying over it in small herds of people ("Herumwirrend und in kleine Heerden zertheilt", p.191) and during the summer possibly venturing even farther than the $80^{\text {th }}$ parallel north, to the very edge of the inhabitable world. The build of the Eskimos is very much dependent on their habitat: these "nördlichen Zwerge" - "northern dwarfs" (p.215) are four feet at most, and they are fat, stocky and misshaped because the extreme cold naturally compresses and degrades all life. Their diet also contributes to the peculiarity of the Eskimos: the exclusive consumption of oily fish has resulted in the fact that "ihr Fleisch davon die Substanz bekommen [hat]" - "their flesh is now of that same substance" (p.206). Moreover, Eskimo women are the only humans licking their new-born babies, since these are covered with slime similar to that of scale-less fish.

What the Eskimos have in common with all Americans is their general lack of body hair and growth of beard - one of the main signs of degeneracy, as de Pauw uses it as a point of reference for every people he describes - as well as their temperament. Relating back to the Four Humour Theory, de Pauw describes them as melancholy due to their thick blood; in addition they are cowardly and wild because they are aware of their own weakness. This awareness is exemplified in the fact that the Eskimos offer their wives to strong and superior strangers in the hope of improving their lineage (cf. p.214f). According to de Pauw this lack of jealousy towards another man is not surprising considering the general lack ardour for women that all Americans display (cf. p.47ff). The only time in which they can be said to be daring is out of necessity during fishing on the sea because this is their only supply of food.

In addition to this description the clergyman backs up his account by very critically referring to travel journals and similar reports on the Eskimos. He credits the Bishop Egede with credibility as he has lived for fifteen years among the Greenlanders - who are the same people as the Eskimos (cf. p.201) - but ridicules many others: "Ich übergehe die Beschreibung, welche uns von Grönland der Mönch Mesanges geliefert, der nicht richtig im Kopfe gewesen 
zu seyn scheint, als er dieses abgeschmackte Werk zusammengestoppelt hat" - "I ignore the description of Greenland provided to us by the monk Mesanges who seems not to have been in his right mind when he was cobbling together this tasteless work" (p.199).

De Pauw takes up a similar structure for describing the Patagonians. After briefly referring to their habitat and its soil, he quickly moves on to debunking the widespread belief that the Patagonians are giants: "Ihre Statur ist wie der Europäer ihre" - "Their build is

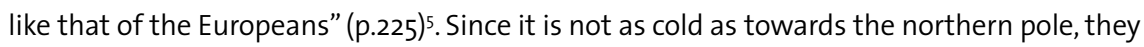
are not as small as the Eskimos, but like them the Patagonians have neither growth of beard nor any other body hair and their moral character does not differ from that of the other American peoples either. De Pauw then spends twenty pages to trace back the myths of the Patagonian giant, giving both the time and the name of the authors of several accounts, relating their conflicting nature and dismissing them as not being conclusive evidence. (Physical evidence in the shape of bones he dismisses by saying that the bones actually belonged to animals and were simply mistaken for human bones (cf. p.246).)

With his account of the Eskimos and the Patagonians de Pauw thus creates the first steps of an image of weak and both mentally and physically different Americans. He implies a certain scientific appeal of his writings by adhering to a particular structure, i.e. going from a description of the habitat to one of the people itself and to a critical analysis of the existing sources. Throughout the Recherches, the various points of difference between the inhabitants of the New and the Old World, but also among the Americans themselves, are strengthened and underlined. Their inappropriate understanding of beauty and the nonexistence of American art relate back to the general lack of abstract concepts on which de Pauw elaborates in the second volume. In contrast, the first volume focuses more on the physical and temperamental differences, such as the missing facial and body hair and the cowardice and lacking ardour for their women respectively.

However, by making a fascinating comparison between manners of the contemporary American to manners that at one point were also known in Europe and other parts of the Old World, de Pauw also emphasises the theory of a stadial development of mankind. Granting that his description of the degenerate American has a very strong negative ring to it - which also was the general interpretation of it, especially by the Americans of European descent - it was not necessarily intended exceptionally in that way. Underlining the backwardness of America in such a contrast to Europe, de Pauw does assert European

5 Interestingly, the ludicrous misbelief in giant people is, according to de Pauw, not only to be found in European travellers. In fact, the Patagonians themselves asked of some English officers if there were giants in Europe - and the officers confirmed that there were (cf. de Pauw, 1769a, p.227). 
superiority but to a certain degree he also takes the blame for their barbarism off the Americans: their current state of being is not self-inflicted but rather naturally due to their early stage of development. At one point in history, for instance, the Gauls and Scythians too had such repelling customs as burying living servants or wives with a dead chief or patriarch (cf. de Pauw, 176gb, p.166ff) but as societies progressed these customs were rejected. In fact, de Pauw spends a complete section in his second volume to speak "Von einigen närrischen Gebräuchen, die alle Welttheile miteinander gemein haben" - "Of some foolish customs that all parts of the world have in common".

Consequently one can say that the differences between the peoples of the Old and the New World lie in the discrepancy between their respective levels of development towards civilisation. As pointed out before, the reason for this discrepancy is to be found in the negative effects of America's cold and wet climate which translates itself onto the continent's fauna and flora. With regard to the Americans, the marked differences relate to their want of certain physical and mental endowments. All of these are signs for the Americans' state of barbarism and their lack of civilisation.

\section{Reinterpreting Buffon: The Degeneracy Theory ${ }^{6}$}

Many if not all of these ideas of de Pauw relate back to the writings of the French naturalist Georges-Louis Leclerc, Count de Buffon. ${ }^{7}$ In his Histoire Naturelle: Générale et Particulaire (thirty-six volumes between 1749 and 1788) Buffon aims at giving a history of life on earth, covering zoology, mineralogy and botany. Like the Encyclopédie, it is very much an Enlightenment enterprise and tries to account for contemporary scientific knowledge of nature. Among other things, the Count compares quadrupeds from the New World to those of the Old World, and "discovers" that the American specimens are without exception smaller to their European, African or Asian counterparts. His conclusion is simply that in general "Living nature is thus much less active there (in America), much less varied, and we may even say, less strong" (quoted in Gerbi, 2010, p.4). I will follow Henry Ward Church in quoting Thomas Jefferson's "excellent summary" of Buffon's theory:

6 I would like to thank Margaret Meredith for her valuable help with understanding Buffon and his writings.

7 For a detailed and elaborate account and analysis of the degeneracy theory, its arguments, proponents and opponents, and development, I recommend Antonello Gerbi's 1955 masterly monograph The Dispute of the New World - The History of a Polemic, 1750-1900. 
"The opinion advanced by the Count de Buffon is 1. That the animals common to both the old and new world are smaller in the latter. 2. That those peculiar to the new are on a smaller scale. 3 . That those which have been domesticated in both have degenerated in America; and 4. That on the whole it exhibits fewer species. And the reason he thinks is, that the heats of America are less; that more waters are spread over its surface by nature, and fewer of these drained off by the hand of man. In other words, that heat is friendly, and moisture adverse to the production and development of large quadrupeds" (quoted in Church, 1936, p.189).

However, while many people (Jefferson among them) understood Buffon's theory as an attack on America, the naturalist's idea of degeneration was not intended as a theory for a country's backwardness. In Buffon degeneration rather serves as a mechanism for change. In his essay "Of the Degeneration of Animals", he gives an account of change in man and animals: changes in colour occur due to climate; " $(t)$ he other changes, such as those of stature, figure, features, and quality of the hair, seem to require the joint operations of climate and other causes" (Buffon, 1781, p.394), these other causes mainly being the respective diet.

The fact that de Pauw bases his own work on that of Buffon is in itself not unusual since this was an established practice. However, he often does not explicitly refer to Buffon as his source although he definitely takes his main arguments from the French naturalist, and one might even go so far to say that the clergyman plagiarised, so similar are some of the arguments and examples. Still, de Pauw does not wholly agree with Buffon. The disagreement lies mainly in the count's assertion that America is a younger continent that was only recently populated (cf. de Pauw, 1769a, p.18f). De Pauw prefers the explanation of one or several floods as the cause for the unfavourable conditions in the New World because he cannot agree with the implication that a younger continent should be as feeble and decrepit as America. However, while they may disagree with respect to the cause of the conditions, their characterisation of the American climate is one and the same: it is wet, and it is cold. For de Pauw, the only logical consequence to these circumstances is degenerate life. The Eskimos, for instance, are "zusammengepresst" - "compressed" and live in misery, as do the Patagonians and every other American people. Still, initially this weakness has not necessarily been the Americans' fault as the origins of their state lie in the climate and diet and are thus conditioned by the nature of their habitat.

In spite of this, de Pauw's transformation of Buffon's degeneration mechanism for change into a more encompassing explanatory theory of degeneracy, which is evident throughout the Recherches, comes to get a strong negative connotation. For instance, he 
speeds up the process of degeneration and applies it more generally to man. Whereas for Buffon it was evident that change takes considerable time and that especially human kind is rather stable (cf. Buffon, 1781, p.395f), in de Pauw change itself not only happens much faster but also affects man much faster. The descendants of Europeans in America thus all show the signs of degeneracy. The clergyman writes that:

\begin{abstract}
"Aus den Beobachtungen der Kreolen ergibt sich, daß sie, so wie die amerikanischen Kinder, in ihrer zarten Jugend, einige Merkmale der Einsicht äussern, welche aber verlöscht, wenn sie in das männliche Alter treten: sie werden alsdenn nachläßig, stumpf, [...] und gelangen nicht zur Vollkommenheit einer Wissenschaft, oder Kunst." - "From observing the Creoles $^{8}$ results the fact that they, as the American children, show some signs of intellect in their early youth, which however fades once they enter adulthood: they then become careless, dull [...] and don't arrive at the excellency of the sciences or the arts." (de Pauw, 1769b, p.131)
\end{abstract}

The observation that the mental capacities of Europeans settling in America will decline surely played well into the hands of Frederick the Great and his anti-emigration policy. It also serves to once again underline the disadvantageous conditions of the New World, this time not only with respect to its native inhabitants who have been subject to the wet and cold for centuries but also with respect to recent immigrants.

These accusations of inferiority naturally did not go unchallenged. Especially people living in the New World were sensitive to the negative undertone of de Pauw's essay and tried to contest it. The Founding Fathers of the United States, for instance, wished as much to attract immigrants as Frederick the Great tried to prevent them. The probably most famous attempt at disproving the degeneracy theory in this context was undertaken by Thomas Jefferson. He spent a considerable amount of pages of his Notes on the State of Virginia (1785) - from which the above quoted summary of the French naturalist's position is taken - as a means of debunking Buffon's theory as he understood it. Almost obsessive though were his - ultimately successful - attempts at presenting the Count with the skeleton of a moose, preferably seven feet high. Alan Lee Dugatkin writes in his Mr. Jefferson and the Giant Moose:

8 De Pauw defines Creoles as "Europäer, die in Amerika zwar gebohren sind, aber Eltern von unsrer Welt gehabt haben" - "Europeans who were born in America but had parents from our world“(de Pauw, 1769 b, p.130). 
“Jefferson's most concerted effort in terms of hands-on evidence was to procure a very large, dead, stuffed American moose-antlers and all-to hand Buffon personally, in effect saying "see." This moose became a symbol for Jefferson - a symbol of the quashing of European arrogance in the form of degeneracy" (2009, p.xi).

However, Buffon died within six months after he had received the moose and therefore, even though he had allegedly recognised his mistake, at least with regard to the degeneration of all American animals, he never came to "set these things right" (quoted in Dugatkin, 2009, p.100).

Jefferson was not the only one aware of the implications of the idea of degeneration, althoug his interpretation of Buffon comes closer to the contents of de Pauw's Recherches and his transformation of the degeneration mechanism into the degeneracy theory. Several South Americans, Jesuits among them, in fact explicitly reacted to de Pauw and composed lengthy responses to his polemic in which they tried to convey their own image of America. John Browning claims that "(h)ad de Pauw turned his attention elsewhere, it is very likely that these valuable natural histories would have been less impassioned. They would probably have been briefer too" (1978, p.295). The Mexican Clavijero, for instance, is furious with de Pauw and his "calumnies and insolence" (quoted in Browning, 1978, p.295). One clearly unexpected effect of the Recherches was thus the rise of Spanish American sentiments of nationalism that grew with writers such as Clavijero in defence of their home countries.

\section{Conclusion}

The degeneracy theory was consequently not only highly controversial from the beginning but also already, although only partly, successfully contested by different writers. Nonetheless it kept being very attractive to European thinkers, and Antonello Gerbi ends his monograph on the Dispute of the New World only after discussing Hegel, Kant, Goethe, Dickens and many others more who were involved in the polemic. And even though his analysis concludes in 1900, this does not mean that the ideas of the theory were gone with the beginning of the twentieth century. Despite Jefferson's moose, and despite the highly positive accounts by Clavijero and others, traces of the idea that the New World was at least partly inferior to the Old lingered on. In Arthur Conan Doyle's 1912 scientific romance The Lost World, statements of the narrator are reminiscent of the degeneracy theory with regard to America's fauna. While traveling through the Amazon rain forest the narrator notes: 
"Alone, I should have been ignorant of the names of these giant growths but our men of science pointed out the cedars, the great silk cotton trees, and the redwood trees, with all that profusion of various plants which has made this continent the chief supplier to the human race of those gifts of nature which depend upon the vegetable world, while it is the most backward in those products which come from animal life" (Conan Doyle, 2010, p.56, emphasis mine)9.

While its proponents like Cornelius de Pauw may be forgotten, this example underlines the immense influence of the inferiority idea on the theoretical framework of the Old World. For some, the degeneracy theory is indeed the root of modern day anti-Americanism, which James Ceaser describes as "one of the most powerful modes of thought in the world today" (2003, p.4). In his Genealogy of anti-Americanism, Ceaser claims that only an understanding of the intellectual history of anti-Americanism can lead to a "genuine dialogue between America and Europe" (p.17). Understanding how de Pauw used Buffon and how de Pauw was received and interpreted by his contemporaries thus can be a first step to untangle the intellectual strands that still seems to inform current political thinking.

The far-reaching implications of the Recherches Philosophiques sur les Américains therefore make it not only a fascinating but also a relevant read. Cornelius de Pauw's rich writing uses contemporary scientific theories to convey an image of the Americas and its peoples as degenerate and with a negative effect on Europe. But at the same time his Enlightenment background has him criticise European imperial behaviour and imply the possibility for America to improve and with the help of agriculture to master nature and move towards civilisation.

9 Interestingly enough, there are more traces of de Pauw in The Lost World. The ape-men that are described as the "Missin' Links" (Conan Doyle, 2010, p.117) between apes and men are in their appearance very similar to the Orang-Utan - whose description by de Pauw is summed up as them being "Mittelwesen"- "in-between beings". 


\section{Bibliography}

Aa,A.J.van der (1872). Pauw (Cornelius). In Biographisch woordenboek der Nederlanden, bevattende levensbeschrijvingen van zoodanige Personen, die zich op eenigerlei wijze in ons Vaderland hebben vermaard gemaakt. (Vol. 15, pp. 140-141). Haarlem: J.J. van Brederode.

Antoine-Joseph Pernety (n.d.). Retrieved June 8, 2013 from http://www.universalis.fr/ encyclopedie/antoine-joseph-pernety/

Beyerhaus, G. (1926). Abbé de Pauw und Friedrich der Große, eine Abrechnung mit Voltaire. Historische Zeitschrift 134(3), 465-493.

Browning, J.D. (1978). Cornelius de Pauw and Exiled Jesuits. Eighteenth-Century Studies 11(3), 289307.

Buffon, Count de (1781). Natural History: General and Particular, by the Count de Buffon, Vol. VII (W. Smellie, transl.). (original work published 1749-1788). s.n.

Buffon, Count de (1791). Natural History: General and Particular, by the Count de Buffon, Vol. V (W. Smellie, transl.). (original work published 1749-1788). London: Strahan \& Cadell in the Strand.

Carlyle, E.I. (1899). Webb, Daniel. In Dictionary of National Biographies, 1885-1900, Vol. 60.

Ceaser, J.W. (2003). A genealogy of anti-Americanism. The Public Interest 152, 3-18.

Chinard, G. (1947). Eighteenth Century Theories on America as a Human Habitat. Proceedings of the American Philosophical Society 91(1), 27-57.

Church, H.W. (1936). Corneille de Pauw, and the Controversy over his 'Recherches Philosophiques sur les Américains'. PMLA 51(1), 178-206.

Conan Doyle, A. (2010). 'The Lost World' \& Other Stories. Ware: Wordsworth Editions Limited.

Dugatkin, L.A. (2009). Mr. Jefferson and the Giant Moose - Natural History in Early America. Chicago and London: The University of Chicago Press.

Gerbi, A. (2010). The Dispute of the New World - The History of a Polemic, 1750-1950. Pittsburgh: University of Pittsburgh Press. 
Ingrao, C. (1986). The Problem of "Enlightened Absolutism" and the German States. The Journal of Modern History 58 (Supplement: Politics and Society in the Holy Roman Empire, 1500-1806), $161-180$.

Iselin, I. (1770). Pauw, C. de: 'Recherches Philosophiques sur les Américains.' Rezension. In: Allgemeine Deutsche Bibliothek XII( 1), 114-139. Berlin and Stettin: Friedrich Nicolaí.

Lacorne, D. (2005). Anti-Americanism and Americanophobia: A French Perspective. In T. Judt \& D. Lacorne. With Us or Against Us. Essays on Global Anti-Americanism (pp. 35-58). New York: Palgrave.

Muthu, S. (2003). Enlightenment against Empire. Princeton: Princeton University Press.

Palmer, R.R. \& Colton, J. (2006). A History of the Modern World (10 ${ }^{\text {th }}$ ed.). New York etc.: McGrawHill.

Pauw, C, de. (1769a). Philosophische Untersuchungen über die Amerikaner, oder wichtige Beyträge zur Geschichte des Menschlichen Geschlechts, Band 1. Berlin: Decker und Winter.

Pauw, C, de. (176gb). Philosophische Untersuchungen über die Amerikaner, oder wichtige Beyträge zur Geschichte des Menschlichen Geschlechts, Band 2. Berlin: Decker und Winter.

Pauw, C, de. (1771). Recherches philosophiques sur les Américains ou mémoires intéressants pour servir à l'histoire de l'espèce humaine / par Mr. de $P^{* * *}$. Berlin: s.n.

Pauw, C, de. (1789). Selections from Les Recherches Philosophiques sur les Américains of M. Pauw. By Mr. W***. Bath : R. Cruttwell.

Salzmann, K.H. (1957). Decker, Georg Jakob. In Neue Deutsche Biographie (Vol. 3, pp. 547-548).

Stolberg-Wernigerode, Otto Graf zu (1961). Friedrich II. der Große. In Neue Deutsche Biographie (Vol. 5, pp. 545-558).

Taylor, Q. (n.d.). United States History: Timeline 1700-1800. Retrieved May 11, 2013 from http://faculty.washington.edu/qtaylor/a_us_history/1700_1800_timeline.htm.

Thompson, C. (2011). Travel Writing. London - New York: Routledge. 

Japan 


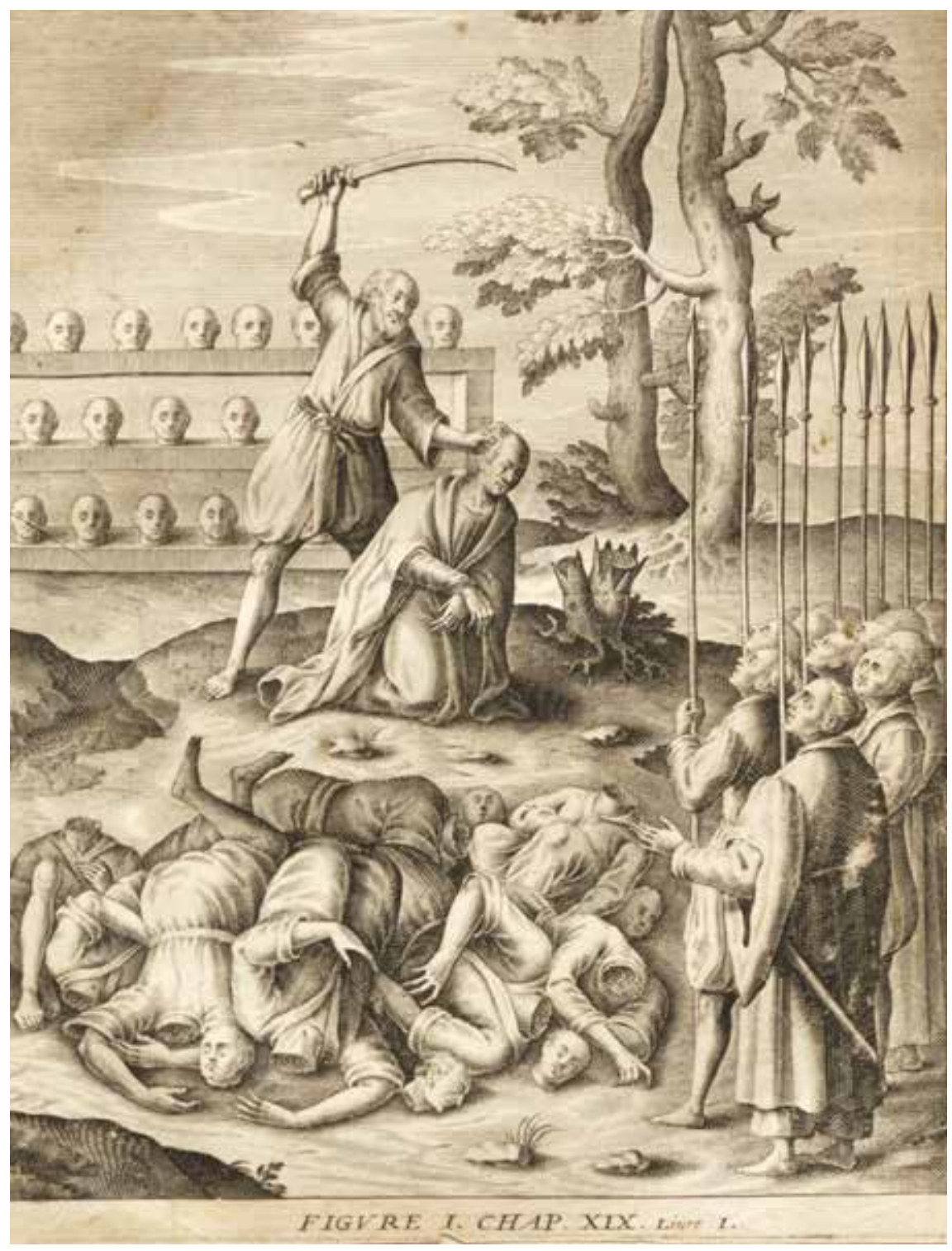

The persecution of the Jesuit priest Matthias and his converts in Japan.

Source: Trigaut, N. (1624). Histoire des martyrs dv lapon depuis l'an MDCXII iusques a MDCXX. Paris: Sebastien Cramoisy, p. 93 . 